\title{
Upregulation of Jasmonate-Inducible Defense Proteins and Differential Colonization of Roots of Oryza sativa Cultivars with the Endophyte Azoarcus sp.
}

\author{
Lucie Miché,, ${ }^{1}$ Federico Battistoni,, ${ }^{1}$ Sabrina Gemmer, ${ }^{1}$ Maya Belghazi, ${ }^{2}$ and Barbara Reinhold-Hurek \\ ${ }^{1}$ Laboratory of General Microbiology, Faculty of Biology and Chemistry, University of Bremen, PO. Box 334040 , \\ D-28334 Bremen, Germany; ${ }^{2}$ INRA-UMR 6175 PRC, Service de spectrométrie de masse pour la protéomique, \\ 37380 Nouzilly, France
}

Submitted 13 July 2005. Accepted 27 December 2005.

The endophyte Azoarcus sp. strain BH72 expresses nitrogenase (nif) genes inside rice roots. We applied a proteomic approach to dissect responses of rice roots toward bacterial colonization and jasmonic acid (JA) treatment. Two sister lineages of Oryza sativa were analyzed with cv. IR42 showing a less compatible interaction with the Azoarcus sp. resulting in slight root browning whereas cv. IR36 was successfully colonized as determined by nifH::gusA activity. External addition of $\mathrm{JA}$ inhibited colonization of roots and caused browning in contrast to the addition of ethylene, applied as ethephon (up to $5 \mathrm{mM}$ ). Only two of the proteins induced in cv. IR36 by JA were also induced by the endophyte (SalT, two isoforms). In contrast, seven JA-induced proteins were also induced by bacteria in cv. IR42, indicating that IR42 showed a stronger defense response. Mass spectrometry analysis identified these proteins as pathogenesis-related (PR) proteins (Prb1, RSOsPR10) or proteins sharing domains with receptorlike kinases induced by pathogens. Proteins strongly induced in roots in both varieties by JA were identified as Bowman-Birk trypsin inhibittors, germinlike protein, putative endo-1,3-beta-Dglucosidase, glutathion-S-transferase, and 1-propane-1carboxylate oxidase synthase, peroxidase precursor, PR10a, and a RAN protein previously not found to be JAinduced. Data suggest that plant defense responses involving JA may contribute to restricting endophytic colonization in grasses. Remarkably, in a compatible interaction with endophytes, JA-inducible stress or defense responses are apparently not important.

Additional keywords: proteome, $\beta$-glucuronidase.

Several nitrogen-fixing, non-nodule inducing bacteria have been recognized as endophytes of suborder Gramineae, such as Azoarcus spp. in Kallar grass and rice (Hurek et al. 1994; Reinhold et al. 1986), Herbaspirillum seropedicae in sugar cane (James and Olivares 1998) and sorghum (James et al. 1997), or Gluconacetobacter diazotrophicus in sugar cane (James et al. 1994). These species differ markedly from other symbiotic or plant-colonizing bacteria such as Rhizobium or

Corresponding author: Barbara Reinhold-Hurek; E-mail: breinhold@unibremen.de; Telephone: +(49) 421-218 2370; Fax: +(49) 421-218 9058.

Current address for L. Miché: CIRAD-UMR BGPI, Campus International de Baillarguet, TA 41/K, 34398 Montpellier Cedex 05, France.
Azospirillum spp. in that they are tightly associated with plants: they do not survive well in, and often can not be isolated from, root-free soil (James and Olivares 1998; ReinholdHurek and Hurek 1998b).

These nitrogen-fixing endophytes share pathways of infection and colonization of grass roots (James and Olivares 1998; Reinhold-Hurek and Hurek 1998b), which were also detected in rhizobia colonizing rice (Yanni et al. 1997). Infection occurs at the emergence points of lateral roots and in the zone of elongation and differentiation above the root tip. The major colonization sites are the outer root cell layers and the root cortex or aerenchyma in flood-tolerant plants; as for plant some pathogens, ingress into the stele and specifically into xylem cells is also observed for endophytes, albeit rarely. Although intracellular colonization occurs in addition to intercellular localization, there is no evidence for an endosymbiosis in living plant cells (James and Olivares 1998; Reinhold-Hurek and Hurek 1998a) as in the legume symbiosis. High numbers of culturable bacterial cells in roots have been reported (up to $10^{8}$ per gram of root dry weight); however, no symptoms of disease are found under natural conditions (Barraquio et al. 1997; Reinhold et al. 1986). Thus, the host interactions of these endophytes lie between a pathogenic and endosymbiotic lifestyle.

With respect to possible roles of these endophytes, there are numerous reports of plant-growth promotion (Hurek et al. 1994; James and Olivares 1998; Yanni et al. 1997). In addition, the contribution of fixed nitrogen to a grass by a specific endophyte has recently been proven in a few cases, such as for Gluconacetobacter diazotrophicus and sugar cane (Sevilla et al. 2001), Azoarcus sp. strain BH72 and Kallar grass (Hurek et al. 2002), or Klebsiella sp. and wheat (Iniguez et al. 2004). In gnotobiotic cultures, also, rice is internally colonized by Azoarcus sp. strain BH72 (Hurek et al. 1994) and nitrogenase genes are expressed in the aerenchyma of rice roots (Egener et al. 1999).

Since the rice genome sequence is known (Goff et al. 2002; Yu et al. 2002) and the genome of strain BH72 is currently sequenced (Hurek and Reinhold-Hurek 2003), mechanisms of initial interactions can be studied by functional genomic and proteomic approaches in this system. Information on responses of any tissues of graminaceous plants to endophytic colonization is scarce. Except for expressed sequence tags reported for the root to stem transition zone of the sucrose-accumulating plant sugar cane infected by Gluconacetobacter or Herbaspirillum spp., there are no data on responses of roots, the main colonization sites in rice and other grasses. Moreover, informa- 
tion about the response of rice roots to microbial colonization in general is scarce, since the important pathogens in paddy rice culture mostly attack the aerial part of the plant.

In general, jasmonic acid (JA) and salicylic acid (SA) are key signaling phytohormones in numerous plant responses to stresses such as pathogen attack and exposure to fungal elicitors (Berger 2002; Kunkel and Brooks 2002); however, recent studies suggest that, in rice especially, JA plays an important role in defense mechanisms (Kim et al. 2003; Rakwal and Komatsu 2000). Also, in symbiotic interactions such as arbuscular mycorrhiza, plant defense responses are triggered during early stages (Liu et al. 2003). In the graminaceous plant barley, colonization by an arbuscular fungus leads to elevated levels of JA (Hause et al. 2002). For dicotyledonous plants (Rosidae spp.), it has been suggested that plant defense responses mediated by ethylene and SA are involved in the regulation of enteric endophytic colonization (Iniguez et al. 2005). Here, we applied proteome analysis of Oryza sativa roots to study the extent to which a plant defense response might be involved in the interaction of an Azoarcus sp. with different cultivars.

\section{RESULTS AND DISCUSSION}

Rice varieties are differentially colonized by an Azoarcus sp.

Physiologically successful root colonization of the endophyte Azoarcus sp. strain $\mathrm{BH} 72$ can be monitored by visualization of transcriptional activation of bacterial nitrogenase genes in or on roots, using an isogenic reporter strain (BHGN3.1) carrying a transcriptional nifH::gusA fusion (Egener et al. 1999). While intense $\beta$-glucuronidase (GUS) staining had previously been observed for Oryza sativa cv. nipponnbare (Egener et al. 1999), a screen of different indica-type rice varieties revealed differential colonization of roots by Azoarcus strains; cultivar IR36 showed nifH::gusA expression throughout the root system (Fig. 1A, panel 1), in concordance with the previous observation of endophytic colonization of this variety (Hurek et al. 1994), whereas GUS staining was much less intense for IR42 (Fig. 1A, panel 2). Moreover, IR42 developed a slight brownish root color upon inoculation with Azoarcus sp. strain BHGN3.1, indicative of a less compatible interaction with the bacterium. This root browning morphologically resembled a defense response of roots to pathogens and is putatively due to the accumulation of phenolic compounds. Varieties $O$. sativa cvs. IR36 and IR42 are sister lineages from the same cross that have similar diseaseresistance profiles; however, in contrast to IR42, IR36 is moderately resistant to the brown grasshopper biovar 3 and is more tolerant to flooding. Thus there are no obvious explanations for different colonization responses to bacterial endophytes. Future applications of endophytes will, however, require a better understanding of host-range restrictions to these bacteria.

\section{Elevated levels \\ of JA prevent physiologically successful colonization.}

To gain insight into the signaling pathways that might be involved, we tested how rice roots respond to known signaling molecules, such as jasmonate, salicylate, or ethylene. JA (100 $\mu \mathrm{M})$ or SA $(1 \mathrm{mM})$ were added to the plant medium of $\mathrm{cv}$. IR42 without bacterial inoculation. SA did not induce visible changes of root color (not shown), whereas addition of JA resulted in brownish roots (Fig. 1C). Cross-sections showed that, in comparison with that in untreated roots (Fig. 1B), the brownish compounds were accumulated in the same region in
1
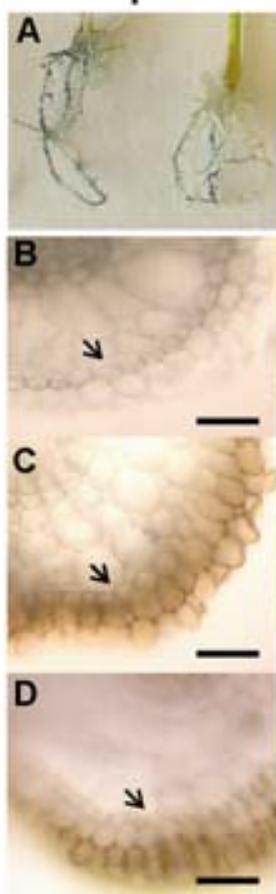

2
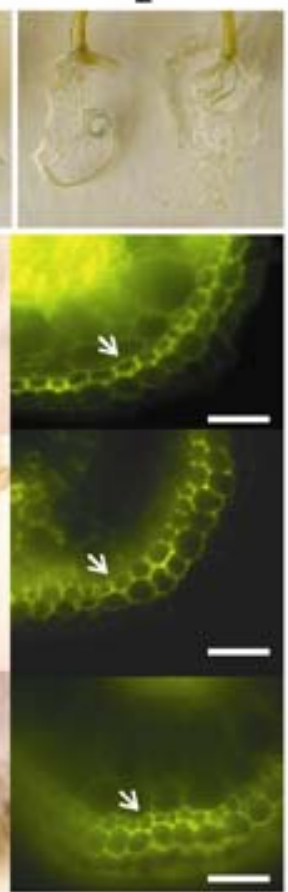

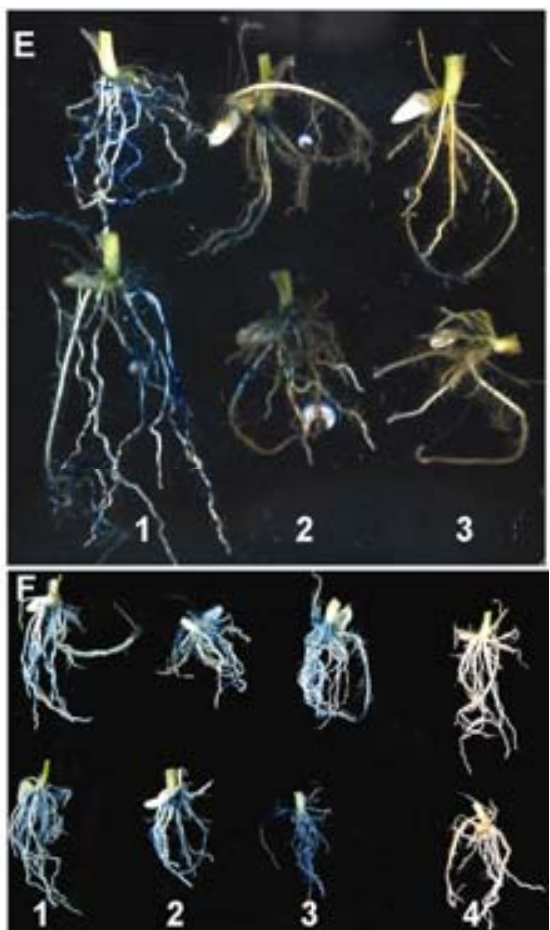

Fig. 1. Response of rice roots to bacterial inoculation and external application of jasmonic acid (JA). A, Roots of Oryza sativa cv. IR36 (panel 1) or cv. IR 42 (panel 2) inoculated with strain BHGN3.1 at $10^{7}$ cells per gram of quartz sand and, at day 15 after inoculation, stained for nifH::gusA activity with X-Gluc. B through D, Light microscopic (panel 1) or fluorescence microscopic images (panel 2) (excitation 450 to $490 \mathrm{~nm}$ ) of hand sections of roots. Arrows point to sclerenchyma. Bars $=50 \mu \mathrm{m}$. Transversal sections of roots from seedlings of $O$. sativa $\mathrm{cv}$. IR $42 \mathbf{B}$, not inoculated, $\mathbf{C}$, not inoculated but treated with $100 \mu \mathrm{M}$ JA at day 9, or D, inoculated with Azoarcus sp. strain BHGN3.1 at $10^{8}$ cells per gram of quartz sand at day 1 and harvested at day 12. E, Inhibition of physiologically successful colonization by external application of JA, two plants per treatment shown. Seedlings of $O$. sativa cv. IR36 inoculated and stained for $\beta$-glucuronidase (GUS) activity as in A and with no JA (panel 1), with $15 \mu \mathrm{M} \mathrm{JA}$ (panel 2), or with $40 \mu \mathrm{M} \mathrm{JA}$ (panel 3) added at day 1. Neutralized D,Lmalic acid ( $200 \mathrm{mg} /$ liter) was added as a carbon source to enhance infection. F, Physiologically successful colonization in the presence of ethylene applied as ethephon, two plants per treatment shown. Experiment as in E, with Panel 1, no ethephon, Panel 2, $1 \mathrm{mM}$ ethephon, and Panel 3, $5 \mathrm{mM}$ ethephon added. Panel 4, unlike panels 1 through 3 was not stained for GUS activity. Upper plant, no ethephon added; lower plant, 4 mM ethephon added. 
JA-treated roots (Fig. 1C) and roots inoculated with high numbers of bacteria (Fig. 1D); the outer cell layers adjacent to sclerenchyma showed increased cell-wall browning (Fig.1, panel 1) and increased fluorescence (Fig. 1, panel 2). This suggested that plant defense responses might be involved in differential bacterial host specificity and that JA might participate in the signaling pathway leading to rice root changes in less-compatible interactions with the endophyte.

Since external application of JA mimicked the morphological changes of roots of IR42 to the Azoarcus sp., it could be anticipated that JA triggers a root response preventing endophytic colonization. Therefore, we investigated whether elevated levels of JA affected colonization rates in a compatible endophyte-rice interaction. External JA was added to roots in concentrations that still allowed growth of rice seedlings (15 or $40 \mu \mathrm{M}$, respectively). The more-compatible variety IR36 was used, and root colonization was enhanced by addition of an external carbon source (Hurek et al. 1994). Intense GUS staining (nifH::gusA fusion) of roots was detected in inoculated, untreated plants throughout the root system (Fig. 1E, panel 1). GUS staining decreased with the application of increasing JA concentrations (Fig. 1E, panels 2 and 3) and was almost diminished at $40 \mu \mathrm{M}$ JA. This suggested that JA triggered a defense response preventing physiologically successful colonization by this endophyte.

In a similar experiment, JA was replaced by ethylene. It was supplied as ethephon to the root medium in a concentration range used by others ( 0.1 to $1 \mathrm{mM}$ ethephon), and no effect on root color or GUS staining was observed (Fig. 1F). Even the addition at 4 to $5 \mathrm{mM}$ ethephon, which led to partial senescence of shoots (not shown), did not cause root browning or inhibition of endophyte colonization (Fig. 1F). Thus, the observed response in the incompatible cultivar was not likely to be provoked by ethylene.

JA and SA are well known key signaling phytohormones in numerous plant responses to stresses, such as pathogen attack in dicots (Glazebrook 1999), in which SA is necessary for the full expression of both local resistance and SAR (systemic acquired resistance), including pathogenesis-related (PR) proteins. The JA pathway typically regulates response to abiotic stress, defenses against insect herbivores, necrotrophic fungal pathogens, and even against some biotrophic pathogens (Turner et al. 2002). However, recent studies suggest that, in rice shoots especially, JA plays an important role in defense mechanisms. SA levels are comparatively high in rice and did not significantly increase after inoculation with Pseudomonas syringae or the biotrophic fungal pathogen Magnaporthe grisea (Silverman et al. 1995). In contrast, JA possesses the ability to induce a variety of defense-related proteins that are not induced by SA but, e.g., by $M$. grisea (Kim et al. 2003; Rakwal and Komatsu 2000; Rakwal et al. 1999; Silverman et al. 1995). In rice roots, consistent with our observations, application of JA concentrations of $<10 \mu \mathrm{M}$ does not provoke chlorosis or other symptoms of senescence that occur at concentrations of 20 to $40 \mu \mathrm{M}$ (Moons et al. 1997).
The root proteomes

of $O$. sativa cvs. IR36 and IR42 are almost identical.

In order to gain insight into the differential response of the two rice varieties, we applied a proteomic approach. First, the root proteomes of plants grown under aseptic conditions without inoculation were compared for $O$. sativa $\mathrm{cv}$. IR36 and IR42 by two-dimensional polyacrylamide gel electrophoresis (2D-PAGE). With approximately 1,000 spots detectable per gel, a better resolution with fewer distortions of the protein patterns than in several other studies on rice roots (Konishi et al. 2005; Moons et al. 1997; Salekdeh et al. 2002) was achieved. The protein pattern of both varieties without treatment was very similar (Fig. 2A and B). Only four abundant proteins were found to be reproducibly different (201 to 204). Their identification by mass spectrometry (MS) (Table 1) suggests that they are isoforms of the same proteins, with slightly different electrophoretic mobility in both varieties.

\section{Only a few JA-inducible proteins are upregulated in a compatible interaction of an Azoarcus sp. with IR36.}

In order to investigate the response of rice roots in more detail, we compared root proteomes of both $O$. sativa cultivars IR36 and IR42 in response to application of JA and to inoculation with Azoarcus sp. strain BHNG3.1. Among about 1,000 spots detected on the different 2D-PAGE gels, 47 showed reproducible induction patterns after bacterial inoculation (Fig. $2 \mathrm{C}$ and D). Out of those, we focused for further analysis on the spots that were also induced by JA treatment. The other ones, which are labeled in Figure 2 without numbering, appeared to be largely of bacterial origin and will be identified upon completion of the Azoarcus sp. strain $\mathrm{BH} 72$ genome project (Hurek and Reinhold-Hurek 2003).

In comparison with proteins induced upon JA treatment (Fig. $2 \mathrm{E}$ and $\mathrm{F}$ ), only two spots were detected that were induced both by Azoarcus inoculation and by JA in the more compatible cultivar IR36 (Fig. 2C and E). However, induction in the presence of JA was stronger (Fig. 3). These proteins (spot 46 and 47) were identified by MS (Table 2). They both showed homology to SalT, a protein found to be induced by salt and drought stress in rice roots (Claes et al. 1990). SalT induction by salt and JA application has also been detected in rice seedlings (Moons et al. 1997), which suggests an overlap between saltand JA induction of proteins. Recent studies determined that SalT is a cytoplasmic mannose-binding rice lectin that responds to a wide range of stresses, suggesting its implication in a global mechanism of response to environmental stresses (de Souza Filho et al. 2003) and involvement in intracellular regulation and signaling (Van Damme et al. 2004). In our gels, two isoforms could be detected. They may result from posttranslational modifications such as phosphorylation, as four putative phosphorylation sites could be predicted by NetPhos 2_0 on the SalT amino-acid sequence. However, a clear answer about the actual site of phosphorylation could not be obtained from the peptides identified by MS.

For protein spots 55 and 56, a weak induction (1.5 to 1.7 times) could be observed in IR36 following bacterial inocula-

Table 1. Protein spots differing in roots of uninoculated Oryza sativa cultivars IR36 and IR42

\begin{tabular}{|c|c|c|c|c|c|}
\hline \multicolumn{2}{|r|}{ Spot } & \multicolumn{4}{|c|}{ Best matched protein } \\
\hline No. & pI/MM (kDa) & Protein name & Accession no. ${ }^{a}$ & pI/MM (kDa) & $\%$ Coverage $^{b}$ \\
\hline 201 & $6.09 / 57.62$ & Dihydrolipoamide dehydrogenase precursor, putative & 3489480 & $7.21 / 52.61$ & 44 \\
\hline 202 & $4.91 / 49.76$ & Peroxidase & 46981333 & $5.51 / 37.78$ & 10 \\
\hline 203 & $6.36 / 56.47$ & Dihydrolipoamide dehydrogenase precursor, putative & 34894800 & $7.21 / 52.61$ & 38 \\
\hline 204 & $5.03 / 48.78$ & Peroxidase & 46981333 & $5.51 / 37.78$ & 11 \\
\hline
\end{tabular}

${ }^{a}$ National Center for Biotechnology Information accession numbers.

${ }^{\mathrm{b}}$ Proteins identified by nano-liquid chromatography-electron spray ionization-tandem mass spectrometry. 
tion (Fig. 3), however no JA effect could be observed in cv. IR36. MS identified both proteins as members of the PR-10 class of PR proteins, PR10-b and RSOs-PR10, respectively. They are induced by pathogen attack in a wide variety of plants (Hashimoto et al. 2004). RSOsPR10 was rapidly induced in roots of rice seedlings upon salt and drought stress as well as blast-fungus infection and JA application (Hashimoto et al. 2004). This indicates that a weak defense response towards Azoarcus spp. might also be induced in this cultivar IR36. However, since a wide range of proteins was upregulated by JA treatment in rice roots (Fig. $2 \mathrm{E}$ and $\mathrm{D}$, and discussed below) that were not induced by Azoarcus inoculation in IR36, these endo- phytes appear to elicit only a mild stress or defense response in a compatible interaction.

\section{JA-inducible PR proteins upregulated}

in a less compatible interaction of Azoarcus sp. with IR42.

In comparison with that in IR36, the root proteome of cultivar IR42 showed a lower number overall of upregulated proteins upon inoculation with the endophyte (Fig. 2D), as can be expected after a less successful colonization. However, several proteins that were typically induced by JA were also upregulated in IR42 upon inoculation with bacteria (Fig. 2D and F). In common were spots 46 and 47, which showed similar induc-
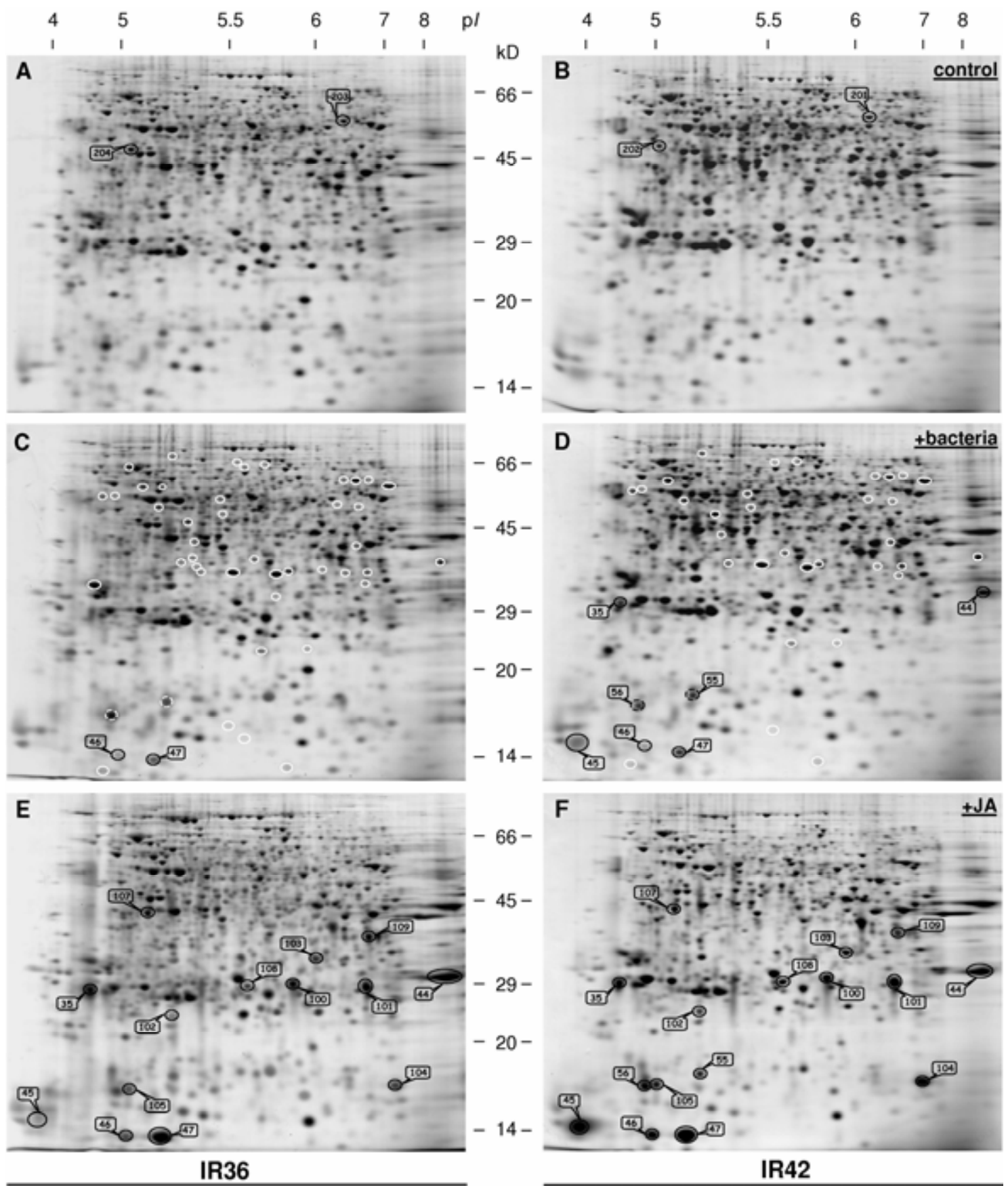

Fig. 2. Coomassie-stained two-dimensional gels of protein extracts from 20-day-old rice roots. Comparison of root proteins induced by bacterial inoculation and jasmonic acid (JA) treatment in Oryza sativa cv. IR36 (A, C, E) and cv. IR42 (B, D, F). A and B, Control roots of rice, harvested 15 days after transfer to plant medium only. C and D, Roots harvested 15 days after inoculation with Azoarcus sp. strain BHGN3.1. White circles indicate proteins induced by bacterial inoculation only. Numbered spots indicate proteins that are induced by both bacterial inoculation and JA treatment. E and $\mathbf{F}$, Roots harvested 15 days after transfer to plant medium and 3 days after JA treatment $(100 \mu \mathrm{M})$. Labeled spots indicate some of the proteins that are induced following JA treatment. 
tion levels as in cv. IR36 (Figs. 2D, F and 3). Two PR proteins (spots 55 and 56) were weakly upregulated in response to bacteria, as in cv. IR36; however, in cv. IR42, they were also induced by JA application (Fig. 3).

Interestingly, the additional spots upregulated in IR42 only were PR proteins. Protein spot 45 was present at a low basal level in cultivar IR42 and was induced (twofold) or strongly induced (sixfold) by bacterial inoculation or JA treatment, respectively (Fig. 3), while it was hardly detectable in cv. IR36. It was identified as protein Prb1 (Table 2), which belongs to a family of $\mathrm{PR}$ proteins, PR-1. This is a dominant protein group induced by pathogens and is commonly used as a marker for-normally SA-related-SAR (van Loon et al. 1998). It was induced in roots of rice seedlings after salt stress or JA treatment (Moons et al. 1997), as well as in JA-treated stems (Rakwal and Komatsu
2000). Thus Prb1 may be a marker for the induction of some defense reaction in cv. IR42 towards Azoarcus spp.

Proteins 35 and 44 were inducible by JA in both varieties; however, only in cv. IR42 were they upregulated in inoculated roots (Table 2 ). They are very similar proteins (55\% aminoacid identity) despite a different isoelectric point ( $\mathrm{pI}$ ) value (Table 2). They show similarities to a new family of receptorlike protein kinases (RLK) that were induced in potato infected by Erwinia carotovora (Montesano et al. 2001). The first member of this family, PvRK20-1, was identified in the roots of common bean (Lange et al. 1999). Interestingly, the transcript level of PVRK20-1 was induced during pathogen attack by Fusarium spp. but remained at the level of the control or was even suppressed upon infection with the nodule-forming symbiont Rhizobium tropici. Relatives of this RLK family were
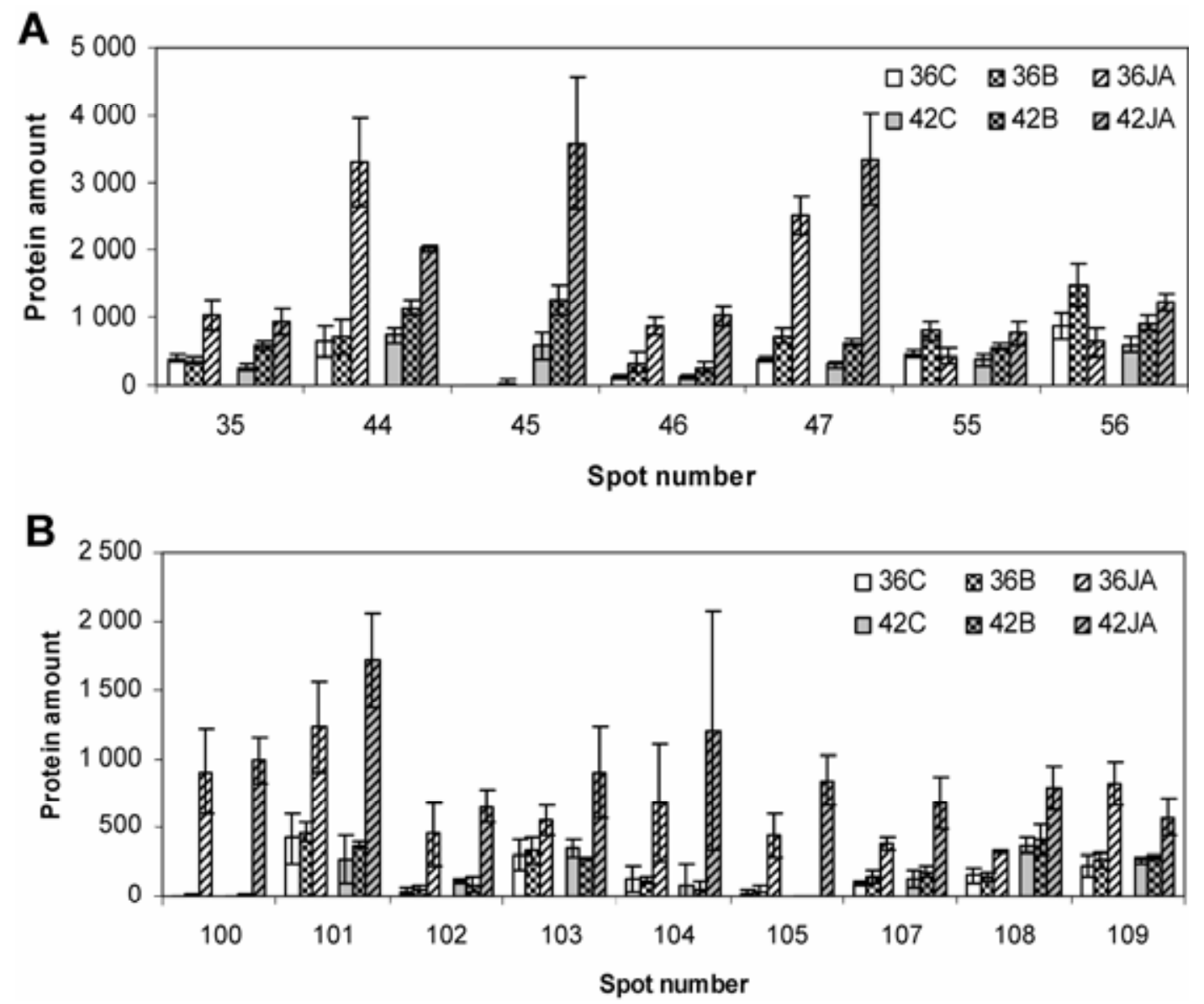

Fig. 3. Quantification of proteins in rice roots induced A, by inoculation with Azoarcus sp. and jasmonic acid (JA) treatment or B, by JA treatment only. Relative spot intensities calculated from three experiments are given with standard deviations (error bars). Two Oryza sativa cultivars IR 36 (36) or IR42 (42) were compared. $\mathrm{C}=$ Uninoculated controls; $\mathrm{B}=$ inoculated with bacteria Azoarcus sp.; JA = treated with JA.

Table 2. Rice root proteins induced both by Azoarcus inoculation and by jasmonic acid (JA) treatment

\begin{tabular}{|c|c|c|c|c|c|}
\hline \multicolumn{2}{|r|}{ Spot } & \multicolumn{4}{|c|}{ Best matched protein } \\
\hline No. & pI/MM (kDa) & Protein name & Accession no. ${ }^{a}$ & $\mathrm{p} I / \mathrm{MM}(\mathrm{kDa})$ & \% Coverage \\
\hline 35 & $4.48 / 30.26$ & Putative receptorlike protein kinase & 19387274 & $5.01 / 27.92$ & $38^{\mathrm{b}, \mathrm{c}}$ \\
\hline 44 & $8.18 / 32.09$ & Membrane binding protein (putative receptor-like protein kinase) & 46399155 & $7.99 / 29.24$ & $11^{\mathrm{c}}$ \\
\hline 45 & $3.79 / 14.67$ & Pathogenesis-related protein (Prb1) & 33440014 & $4.32 / 17.11$ & $42^{c}$ \\
\hline 46 & $4.84 / 14.31$ & Salt-stress induced protein $(\mathrm{SalT})$ & 134190 & $5.20 / 15.18$ & $59^{\mathrm{c}}$ \\
\hline 47 & $5.22 / 13.98$ & Salt-stress induced protein (SalT) & 134190 & $5.20 / 15.18$ & $45^{\mathrm{b}}$ \\
\hline 55 & $5.32 / 18.64$ & Pathogenesis-related protein (PR-10b) & 9230757 & $4.88 / 17.43$ & $41^{\mathrm{b}}$ \\
\hline 56 & $4.75 / 17.74$ & Pathogenesis-related protein (RSOsPR10) & 38678114 & $4.79 / 16.90$ & $84^{\mathrm{b}, \mathrm{c}}$ \\
\hline
\end{tabular}

${ }^{a}$ National Center for Biotechnology Information accession numbers.

${ }^{\mathrm{b}}$ Protein identified by matrix-assisted laser desorption-ionization time-of-flight spectrometry.

${ }^{\mathrm{c}}$ Protein identified by nano-liquid chromatography-electron spray ionization-tandem mass spectrometry. 
also identified in Arabidopsis thaliana. The At-RLK3 gene is expressed at basal level in the entire plant but is activated upon oxidative stress and preferentially during incompatible interaction with the pathogen Ralstonia solanacearum (Czernic et al. 1999). This would indicate a role for this new family of RLK in the early stages of recognition during plant-microbe interactions, with the activation of the receptor-encoding gene leading to the amplification of the signal through increased RLK protein level. It would also correlate with our observation that these proteins are not induced in the compatible rice variety upon infection with Azoarcus strains.

It is also worthwhile noting that spots 35 and 44 encode only the receptor part of those RLK, which possess a duplicated domain containing four conserved cysteines (DUF26) whose function is unknown. Induction of such a truncated version was also observed after inoculation of suspension-cultured rice cells by rice blast fungus as well as by JA treatment (Kim et al. 2003) and in wounded rice leaf sheat (Shen et al. 2003). The fact that this domain is both induced by microorganisms recognized as pathogenic by the plant and also directly by JA treatment, raises a question about the effectors that actually activate this kind of receptor.

\section{Proteins induced by JA treatment only.}

JA application to roots of rice seedlings led to a general decrease in the amount of most proteins, especially in cv. IR42, and to a marked accumulation of a set of defense-related proteins (Fig. 2E and F; Table 3). This is similar to previous observations of others (Moons et al. 1997). A wide range of proteins was induced by JA treatment in both cultivars that were not induced by Azoarcus inoculation, which indicates that there are only partial overlaps of both responses.

By MS analysis, we identified several additional proteins that were relatively strongly induced (Table 3; Fig. 3). Identification of some of them adds further insight into the root proteins regulated by JA in rice, since they had not yet been found as induced in roots. Most proteins were PR proteins. Protein spots 100 and 104 were identified as BBIs (Bowman-Birk inhibitors), which encode serine protease inhibitors. Rice BBI genes are both developmentally regulated and rapidly induced by JA and ethylene as well as in response to pathogen attacks (Qu et al. 2003; Rakwal et al. 2001). Moreover, overexpression of rice RBBI2-3 resulted in strong plant resistance against a fungal pathogen, supporting the view that proteinase inhibitors play an important role in the rice defense system ( $Q u$ et al. 2003). Interestingly, two forms of BBI could be detected in our 2D-PAGE gels. Apart from the classical 16-kDa BBI (spot 104) found in monocotyledonous plants (Liliopsida spp.), another BBI with an unusually greater molecular mass was also induced by JA (spot 100). This protein was also found in stems of rice seedlings treated with JA (Rakwal and Komatsu 2000) and was identified as having an additional third cys-rich domain in the N-terminus (Qu et al. 2003).

As a putative ACC (1-aminocyclopropane-1-carboxylate) oxidase (Table 3), protein spot 107 may catalyze ethylene production. The phytohormone ethylene regulates many different processes in plants and has been implicated in defense responses
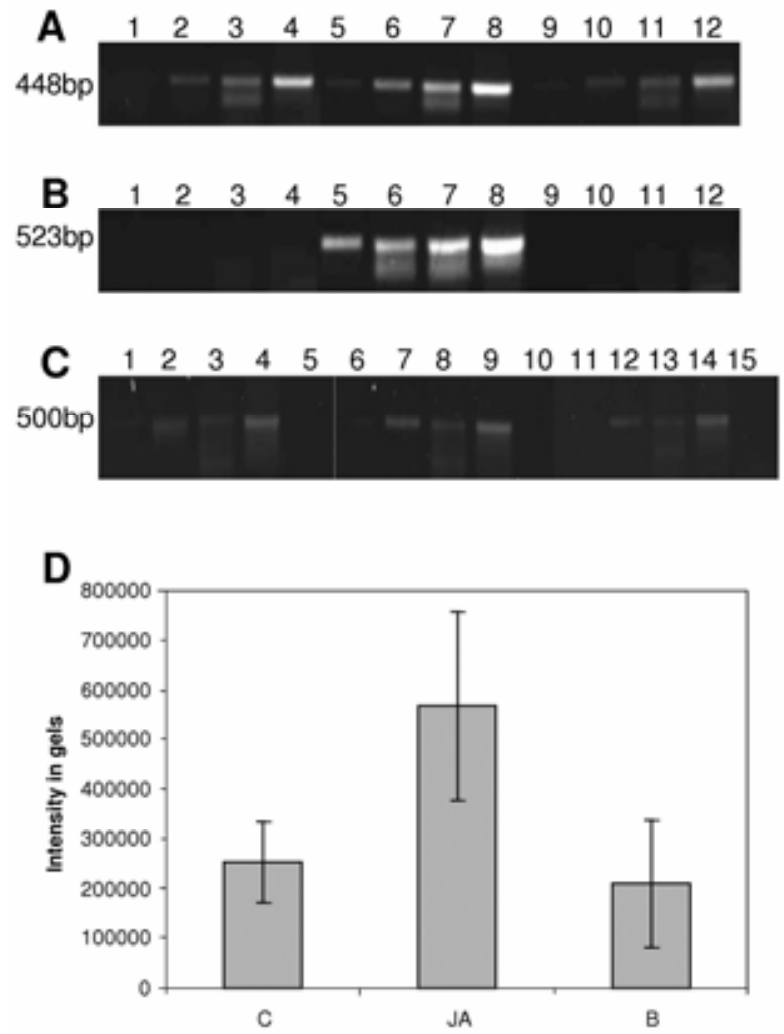

Fig. 4. Analysis of expression of SalT and Bowman-Birk trypsin inhibitor in root RNA of Oryza sativa cv. IR36 by reverse transcriptase-polymerase chain reaction (RT-PCR) analysis. A through $\mathbf{C}$, Amplification products of RTPCR for A, Bowmann-Birk trypsin inhibitor, B, SalT, and C, actin1. In A and $B$ lanes 1 through 4, uninoculated roots; lanes 5 through 8 , jasmonic acid (JA)-treated roots; lanes 9 through 12, roots inoculated with Azoarcus sp. Lanes 1 through 4, 5 through 8, and 9 through 12 each show products of increasing cycle number $(24,28,34$, or 40 cycles, respectively). C, Lanes 1 through 4,6 through 9 , and lanes 11 through 14 show products of increasing cycle number $(24,28,34$, or 40 cycles, respectively) from uninoculated, JAtreated, or inoculated roots, respectively. Lanes 5, 10, and 15 show the DNA controls of these three PCR reactions with inactivated reverse transcriptase. D, Quantification of Bowman-Birk trypsin inhibitor-specific RT-PCR reactions from fluorescence intensities of products obtained after 40 cycles; columns show mean values and standard deviations of fluorescence intensities from three independent repetitions of uninoculated control roots (C), JAtreated roots (JA), and roots inoculated with bacteria (B).

Table 3. Rice root proteins induced only by jasmonic acid (JA) treatment

\begin{tabular}{|c|c|c|c|c|c|}
\hline \multicolumn{2}{|r|}{ Spot } & \multicolumn{4}{|c|}{ Best matched protein } \\
\hline No. & pI/MM (kDa) & Protein name & Accession no. ${ }^{a}$ & pI/MM (kDa) & $\%$ Coverage \\
\hline 100 & $5.83 / 30.55$ & Bowman Birk trypsin inhibitor, putative & 7619799 & $5.40 / 29.25$ & $10^{b}$ \\
\hline 101 & $6.46 / 29.46$ & GTP-binding nuclear protein Ran & 5360230 & $6.66 / 25.02$ & $27^{\mathrm{c}}$ \\
\hline 102 & $5.32 / 26.39$ & zwh0010.1 (oxalate oxidase/germinlike protein) & 5852087 & $6.30 / 25.84$ & $15^{\mathrm{b}, \mathrm{c}}$ \\
\hline 103 & $5.96 / 33.98$ & Glucan endo-1,3-beta-D-glucosidase, putative & 22830909 & $6.96 / 36.91$ & $11^{\mathrm{c}}$ \\
\hline 104 & $6.95 / 17.99$ & Trypsin inhibitor (Bowman-Birk) & 476550 & $7.90 / 16.08$ & $23^{b}$ \\
\hline 105 & $4.88 / 17.55$ & Probenazole-induced protein PBZ1 (PR-10a) & 7442204 & $4.88 / 16.68$ & $25^{\mathrm{c}}$ \\
\hline 107 & $5.13 / 43.20$ & 1-Aminocyclopropane-1-carboxylate oxidase, putative (ACC oxidase) & 51536083 & $5.35 / 35.54$ & $11^{\mathrm{c}}$ \\
\hline 108 & $6.68 / 30.18$ & Glutathione $S$-transferase, putative & 34914740 & $5.67 / 25.35$ & $49^{c}$ \\
\hline 109 & $6.51 / 37.84$ & Class III peroxidase 59 precursor & 5777629 & $6.08 / 36.77$ & $16^{\mathrm{c}}$ \\
\hline
\end{tabular}

${ }^{a}$ National Center for Biotechnology Information accession numbers.

b Protein identified by matrix-assisted laser desorption-ionization time-of-flight spectrometry.

${ }^{c}$ Protein identified by nano-liquid chromatography-electron spray ionization-tandem mass spectrometry 
(Iniguez et al. 2005; Wang et al. 2002). JA and ethylene have also been shown to cooperate in regulating the expression of many genes, and at least some JA-inducible genes are not inducible in plants unable to produce or sense ethylene (Wang et al. 2002). Two defense genes have been shown to be responsive to ethylene in rice, OsPRla (Agrawal et al. 2000) and OsBBIP1 (Rakwal et al. 2001), a member of the Bowman Birk trypsin inhibitor proteins. Concomitant induction of BBIs and the putative ACC oxidase upon JA treatment in our rice roots points to the importance of ethylene as a potential modulator of stress responses in rice.

Spot 102 was identified as a germinlike oxalate oxidase (Table 3). These enzymes are only found in the "true cereals," in which they are involved in defense responses to invasion by fungal pathogens. Their possible modes of action include generation of microcidal concentrations of hydrogen peroxide, elicitation of hypersensitive cell death, and others, as reviewed by Lane (2002).

Protein spot 103 belongs to family 17 of the glycosyl hydrolases, a $\beta$-1,3-glucanase (a PR2). Similar proteins were induced in rice leaves treated with JA (Rakwal et al. 1999). Class PR2 of the PR proteins can inhibit fungal cell growth by hydrolytic degradation of fungal cell walls (van Loon and van Strien 1999).

Protein 105 was identified as PBZ1 (probenazole-induced protein). PBZ1 belongs to the PR-10 class of PR proteins (Hashimoto et al. 2004; McGee et al. 2001). Their biological functions are still unknown, although it has been suggested that some possess a ribonuclease activity (Bantignies et al. 2000). PBZ1 has been reported to accumulate in rice roots treated with JA (Moons et al. 1997), in leaves from whole plant treated with blast fungus (Kim et al. 2003), and in suspension-cultured rice cells in which six isoforms of PBZ1 were induced in response to M. grisea as well as JA treatment (Kim et al. 2003).

Protein spots 108 and 109, identified as putative glutathione $S$-transferase (GST) and peroxidase precursor, were only slightly induced by JA treatment (Table 3). Proteins of this type are known to be involved in cellular protection through reactive oxygen species detoxification. The induction of GST by JA in rice was previously reported (Rakwal et al. 1999), supporting the hypothesis that JA is probably involved in mediating hypersensitive response in rice. Consistent with our results, the induction of a peroxidase precursor matching spot 109 was also reported in rice roots treated with JA (Moons et al. 1997). Apart from peroxide detoxification, this secreted peroxidase may also be involved in lignin biosynthesis (Passardi et al. 2004).

Spot 101 was identified as a RAN protein, a member of GTPases that are involved in the active transport of proteins through nuclear pores and that have been discovered in the Arabidopsis genome in four copies (Vernoud et al. 2003). To our knowledge, this is the first time that this protein has been found to be JA-inducible.

\section{Gene expression analysis}

by reverse transcriptase-polymerase chain reaction.

In order to verify whether differential protein accumulation was accompanied by elevated transcriptional activity, two proteins were selected that either accumulated upon inoculation and JA treatment (SalT) or only upon JA treatment (BBI). Plants were treated as for proteome studies, and RNA extracts from roots were subjected to reverse transcriptase-polymerase chain reaction (RT-PCR) with specific primers (Fig. 4). To obtain results previous to saturation of the PCR reaction, samples were taken at several different cycle numbers and were subjected to gel electrophoresis. As a control for RNA quality, rice actin 1 (Yamaguchi et al. 2002) was used as a constitutively expressed gene (Fig.
4C). The gene encoding SalT was strongly upregulated in JAtreated roots, as expected; however, an induction upon inoculation was not evident (Fig. 4B). The gene encoding the BowmanBirk trypsin inhibitor was expressed in control roots and inoculated roots and appeared to be upregulated in JA-treated roots (Fig. 4A). Band intensities were quantified for three independent repetitions (Fig. 4D), and a statistical analysis was carried out. According to unpaired $t$-test, the ratios of JA-treated to control roots were signifycantly different $(P<0.0035)$ from the ratio of inoculated to control roots for the $B B I$ RT-PCR, while it was not significant for the actin 1 gene, suggesting that $B B I$ was upregulated only upon JA treatment. Similar results were obtained in a second plant experiment (not shown). Despite an overall concurrence of protein and RNA expression analyses, discrepancies in gene expression ratios and protein induction rates may be affected by protein or mRNA stability, depending on timing of the sampling. For example, the $O s B B P I$ induction after JA application is maximal at $6 \mathrm{~h}$ and then gradually declines (Rakwal et al. 2001), which might explain the low gene-induction values we detected three days after application of JA.

\section{Concluding remarks.}

This is the first proteomic report on the response of roots of graminaceous plants towards colonization with endophytic bacteria. Addition of JA, a signal molecule important for stress responses and defense mechanisms in rice, decreased the physiologically successful colonization by the diazotroph Azoarcus sp., suggesting that plant defense responses might control endophytic ingress. This response was not observed for ethylene. Concomitantly, it has been proposed for endophytes of dicotyledonous plants (Rosidae), that plant defense naturally limits infection, albeit based on SA and ethylene as signaling molecules (Iniguez et al. 2005). A proteome approach allowed us to detect only a small overlap in the responses of roots of rice seedlings towards colonization by $\mathrm{N}_{2}$-fixing endophytes and towards JA treatment. In rice variety $O$. sativa $\mathrm{cv}$. IR36 being physiologically successfully colonized by the bacterium, remarkably, only two of the proteins induced by JA were also induced by the endophyte. This indicates that JA-induced stress responses or PR proteins are not important in a compatible interaction with rice. In contrast, the proteome of a sister lineage, cv. IR42, showing a less-compatible interaction with an Azoarcus sp., displayed more overlap (though limited) with JA-induced proteins. They notably included PR-proteins or proteins sharing domains with receptorlike kinases induced by pathogens. This suggests that plant defense responses involving JA do play a role in restricting endophytic colonization in grasses when the host-bacterium interaction is less compatible. It is remarkable, though, that in well-colonized plants, these responses appear to be very limited. In contrast, for other root-colonizing bacteria, such as plant-growth-promoting Pseudomonas fluorescens, a wide range of defense-related genes were induced in the dicotyledonous Arabidopsis (Wang et al. 2005). For future research aiming for applications of endophytic bacteria in a wide range of hosts, it will be important to elucidate which factors are suppressing the defense response in a compatible variety to allow an efficient endophytic colonization.

\section{MATERIALS AND METHODS}

\section{Plant growth and treatments.}

Rice inoculation was done as previously described (Egener et al. 1999). Briefly, Oryza sativa subsp. indica (cv. IR36 or IR42) seeds were surface-sterilized and placed to germinate on agar plates (Hurek et al. 1994). The sterile three- to five-dayold seedlings were transferred to glass tubes containing $5 \mathrm{~g}$ of sterilized quartz sand (Merck, Darmstadt, Germany) saturated 
with nitrogen-free plant medium containing a small amount of neutralized malic acid $(5 \mathrm{mg} / \mathrm{l})$, and were inoculated with a midlogarithmic preculture of Azoarcus sp. strain BHGN3.1 (wild-type BH72 containing nifH::gusA [Egener et al. 1999]) to reach a final concentration of $10^{7}$ bacteria per gram of quartz. Plants were grown for two weeks in a growth chamber at $80 \%$ relative humidity, $30^{\circ} \mathrm{C}$, and $15 \mathrm{kLux}$ light intensity, with a day and night cycle of 14 and $10 \mathrm{~h}$, respectively. Controls were done with noninoculated rice seedlings. For JA treatment, $100 \mu \mathrm{M}( \pm)$ JA (racemic mixture; Sigma, St. Louis) was added to the plant medium of noninoculated seedlings three days before harvesting for proteome analysis. For other experiments, JA was added during transplanting at the concentrations mentioned in the text. Exposure to ethylene was achieved by addition of ethephon to the root medium during transplanting, at concentrations from 0.1 to $5 \mathrm{mM}$ (Camposan Extra, 660 g/liter; Bayer, Leverkusen, Germany). Roots were stained for activity of GUS with X-glu, and light and fluorescent microscopic images were taken with an RGB video camera, as previously described (Egener et al. 1999).

\section{Preparation of total protein extracts.}

Proteins from control and treated plant roots were prepared essentially as by Majoul and associates (2000), with modifications. For roots inoculated with bacteria, successful colonization as nifH::gusA activity was controlled for few plants by staining with X-glu (Egener et al. 1999). Roots from about 30 independently treated seedlings $(1 \mathrm{~g})$ were first ground with quartz powder in liquid nitrogen, then at $4{ }^{\circ} \mathrm{C}$ in $5 \mathrm{ml}$ of extraction buffer $(0.7 \mathrm{M}$ sucrose, $0.5 \mathrm{M}$ Tris, $30 \mathrm{mM} \mathrm{HCl}$, $0.1 \mathrm{M} \mathrm{KCl}, 50 \mathrm{mM}$ EDTA; $2 \%$ [vol/vol] 2-mercaptoethanol and $2 \mathrm{mM}$ phenyl methylsulfonyl fluoride [PMSF] were added just before use). Samples were then extracted with Tris/HCl-buffered phenol ( $\mathrm{pH}$ 8.0). Proteins were precipitated overnight at $-20^{\circ} \mathrm{C}$ with $0.1 \mathrm{M}$ ammonium acetate in methanol and were rinsed and dried under a stream of nitrogen gas. The recovered pellet was solubilized in $200 \mu$ l of protein buffer (5 M urea, $2 \mathrm{M}$ thiourea, 2\% [wt/vol] CHAPS (3-[(3cholamidopropyl)dimethylammonio]-1-propanesulfonate), $2 \%$ [wt/vol] SB 3-10 [ $N$-decyl- $N, N$-dimethyl-3-amino-1-propanesulfonate], 1\% [wt/vol] DTT [dithiothreitol], 2\% [vol/vol], $\mathrm{pH}$ 3 to 10, carrier ampholytes [Bio-Rad, Hercules, CA, U.S.A.]). Protein concentrations in the various extracts were determined using the RC DC protein assay (Bio-Rad) with bovine serum albumin as the standard, and samples were stored at $-80^{\circ} \mathrm{C}$.

\section{D-PAGE.}

For the first dimension, immobilized nonlinear $\mathrm{pH}$ gradient strips were used (Immobiline DryStrips, pH 3 to 10, NL, 18 cm; Amersham Bioscience, Uppsala, Sweden). Strips were rehydrated overnight with protein buffer containing $1 \mathrm{mg}$ of protein extracts. Isoelectrofocusing was performed for a total of $25 \mathrm{kV} / \mathrm{h}$ at $20^{\circ} \mathrm{C}$, using the MultiphorII system (Amersham Biosciences) using a three-phase program. The first phase was set at $500 \mathrm{~V}$, the second was a linear gradient from 500 to $3,500 \mathrm{~V}$, and the final phase was set at 3,500 V. Prior to the second dimension, the gel strips were equilibrated for $2 \times 15 \mathrm{~min}$ in equilibration buffer containing $30 \%(\mathrm{wt} / \mathrm{vol})$ glycerol, $6 \mathrm{M}$ urea, 2\% (wt/vol) sodium dodecyl sulfate (SDS), $50 \mathrm{mM}$ Tris-HCl (pH 6.8). DTT (2\% wt/vol) was added to the first equilibration solution and iodoacetamide $(2.5 \% \mathrm{wt} / \mathrm{vol})$ to the second. Equilibrated gel strips were run overnight on $12.5 \%$ acrylamide gels (30:1). Wide-range molecular markers (Sigma) were loaded beside the strip of some repetition gels to determine apparent molecular masses of the proteins.

\section{Protein staining and analysis of 2D-PAGE gels.}

Coomassie staining of the gels was done according to standard procedures, using a staining solution containing $35 \%$ (vol/vol) methanol, 10\% (vol/vol) acetic acid, and $0.05 \%$ (wt/vol) Coomassie brilliant blue R-250 (Serva, Heidelberg, Germany). Gels were destained with $30 \%$ (vol/vol) methanol, $5 \%(\mathrm{vol} / \mathrm{vol})$ acetic acid solutions and were stored at $4{ }^{\circ} \mathrm{C}$ in storage buffer $(18 \%$ [vol/vol] ethanol, $3 \%$ [vol/vol] glycerol) until analysis.

Stained gels were scanned at 600 dots per inch on a UMAX Power Look III scanner (UMAX, Data Systems, Inc., Taipei, Taiwan), and image analysis was carried out with the ImageMaster 2-D Elite version 4.01 software (Amersham Biosciences). Spot detection, quantification, background subtraction, gel-to-gel matching, and differential display analysis were performed on three independent biological repetitions. Variations are shown in Figure 3. Intensities of individual spots were normalized based upon the total density of all spots detected in each gel. Apparent masses and pIs of each protein spot were calculated by the use of the software, according to the strip gradient and molecular weight ladder used.

\section{Protein identification by MS.}

Differentially expressed proteins reported in this study were either identified by matrix-assisted laser desorption-ionization time-of-flight (MALDI-TOF) or by peptide sequencing using liquid chromatography/tandem MS (LC-MS/MS).

For peptide mass fingerprinting (PMF), spots of interest were manually excised from Coomassie-stained gels and were digested overnight at $37^{\circ} \mathrm{C}$ with modified sequencing-grade trypsin (Roche, Mannheim, Germany). The digested peptides were extracted with acetonitrile $(\mathrm{MeCN}) /$ trifluoro acetic acid (TFA) as described by Shevchenko and associates (1996), with modifications. Samples were evaporated to dryness in a vacuum centrifuge and were redissolved in $0.1 \%$ TFA. Tryptic peptides were then desalted using C18 ZipTip (Millipore Corp. Beverly, MA, U.S.A.) and were eluted in $1 \mu \mathrm{l} \mathrm{MeCN/water} 1: 1,0.1 \%$ TFA. PMF was performed using a Voyager DE-PRO mass spectrometer (Perspective Biosystems, Farmingham, MA, U.S.A.). Peptide extract and a matrix-saturated solution of cyano-4-hydroxycinnamic acid, (Sigma) in 50\% MeCN and $0.1 \%$ TFA were mixed $(0.5 \mu \mathrm{l}$ each), were loaded on the MALDI laser target, and were allowed to crystallize at room temperature for a few minutes before analysis.

The mass spectrometer was operated in the reflector mode with an accelerating voltage of $20 \mathrm{kV}$, and the average spectrum was determined for 500 laser shots per spectrum. Each spectrum was externally mass calibrated by using a standard peptide mixture (Sigma) of angiotensin I, human adrenocorticotropic hormone (ACTH) 1-17 clip, ACTH 18-39 clip, and ACTH 7-38 clip. Protein identification was carried out with the ProFound Advanced software from ProteoMetrics, using the nonredundant NCBI (National Center for Biotechnology Information) database for the search, with parameters as follows: one trypsin missed cleavage allowed, a fixed carbamidomethyl Cys modification, a variable Met oxidation, and variable pI and molecular mass ranges (according to the values expected), until significant score was obtained for the best matched protein and at least three matched peptides.

For MS/MS analyses, digestion of protein spots was modified. Excised spots were reduced with $10 \mathrm{mM}$ DTT for 45 $\min$ at $56^{\circ} \mathrm{C}$ and then were alkylated with $55 \mathrm{mM}$ iodoacetamide in the dark for $30 \mathrm{~min}$. After enzymatic digestion peptides were sequentially extracted with $1 \%$ formic acid for 10 min and $0.1 \%$ formic acid (vol/vol) in $50 \%$ (vol/vol) $\mathrm{MeCN}$ for $15 \mathrm{~min}$. Supernatants were pooled, were evaporated in a vacuum centrifuge, and were redissolved in $0.1 \%$ formic acid 
(vol/vol) in 2\% (vol/vol) MeCN. LC-MS/MS experiments were performed on an electron spray ionization-Q-TOF (QTOF Ultima Global, Waters/Micromass, Manchester, U.K.) equipped with a nano-high-pressure liquid chromatography (Cap LC, Waters/Micromass), using a ten-port zero dead volume valve (Vici-Valco Instruments, Schenhon, Switzerland), enabling fast sample loading on a precolumn (LC-Packings PepMap C18, $5 \mu \mathrm{m}, 100 \AA, 300 \mu \mathrm{m} \times 5 \mathrm{~mm}$ ) at a flow rate of $20 \mu \mathrm{l} / \mathrm{min}$ isocratically with solvent $\mathrm{C}(0.1 \%$ formic acid $)$. The composition of solvents $\mathrm{A}$ and $\mathrm{B}$ were $0.1 \%$ ( $\mathrm{vol} / \mathrm{vol})$ formic acid in 2\% (vol/vol) and $80 \%$ (vol/vol) MeCN, respectively. After washing of the precolumn, the ten-port valve was switched, allowing delivery of the $\mathrm{MeCN}$ gradient at 180 to $200 \mathrm{nl} / \mathrm{min}$ onto the analytical column (Waters Atlantis dC18 m, $3 \mu \mathrm{m} 75 \mu \mathrm{m} \times 150 \mathrm{~mm}$ ) by back-flushing the precolumn. The gradient was from 5 to $60 \% \mathrm{~B}$ in $75 \mathrm{~min}$. The mass spectrometer was calibrated using the CID spectrum of Glu-fibrinopeptide (Sigma) at $500 \mathrm{fmol} / \mu \mathrm{l}$ in $0.1 \%$ formic acid. The Q-TOF was operated in DDA mode with a 1-s MS survey scan on three different precursor ions. CID spectrum acquisition was allowed for up to a total of $10 \mathrm{~s}$ on each precursor ion or stopped when the signal intensity fell below 2 counts per second, before a new MS to MS/MS cycle was started. Precursors were excluded from any further MS/MS experiment for one minute, and singly charged ions were excluded as precursors for MS/MS. Protein identification was carried out using the Mascot MS-MS ion search software from Matrix Science, against the NCBInr database, allowing one trypsin missed cleavage and using a \pm 0.2 -Da mass tolerance, a fixed carbamidomethyl Cys modification and a variable Met oxidation.

\section{RT-PCR analysis.}

The RNA of a pool of approximately 30 roots stored in liquid nitrogen was extracted according to the hot-phenol method (Reinhold-Hurek et al. 1993) with following modifications. An initial incubation step of $60 \mathrm{~min}$ in proteinase $\mathrm{K}$ buffer (200 mM Tris-HCl, pH 8.5, $250 \mathrm{mM} \mathrm{NaCl}, 25 \mathrm{mM}$ EDTA, $0.5 \% \mathrm{SDS}$, and $0.2 \mathrm{mg} / \mathrm{ml}$ proteinase $\mathrm{K}$ ) was followed by two phenol (pH 5.5) extractions, and RNA was precipitated in the presence of Pellet Paint (Novagen, Darmstadt, Germany). DNase I (Roche) treatment was followed by one chloroform-phenol-isoamylalcohol extraction before precipitation. RNA was resuspended in 1× RNA-secure (Ambion, Austin, TX, U.S.A.), RNA concentrations were estimated spectrophotometically, and then, were carefully normalized against the actin 1-specific control RT-PCR. Scanning of ethidium bromide-stained gels (Typhoon 8600 variable mode imager) and the corresponding software ImageQuant (Amersham) were used for the accurate estimation of the band intensities. Forward and reverse primers $(0.5 \mu \mathrm{M})$ were applied for the RT-PCR reactions based on Ready $\bullet$ To $\bullet$ Go RT-PCR beads (Amersham). The RT step was done for $30 \mathrm{~min}$ at $42^{\circ} \mathrm{C}$, followed by inactivation for $5 \mathrm{~min}$ at $95^{\circ} \mathrm{C}$ and by cycling for 1 min at $95^{\circ} \mathrm{C}, 1 \mathrm{~min}$ at the specific annealing temperature, and $1 \mathrm{~min}$ at $72^{\circ} \mathrm{C}$, followed by $5 \mathrm{~min}$ of extension at $72^{\circ} \mathrm{C}$. The specific annealing temperature for the primers amplifying Bowman-Birk trypsin inhibitor (gi7619798), SalT (gi256637), or actin 1 were $62^{\circ} \mathrm{C}, 60^{\circ} \mathrm{C}$, and $56^{\circ} \mathrm{C}$, respectively. The absence of DNA template was controlled by inactivation of the RT prior to the reaction. Primer sequences were: SalT fw, TCGGTGTGGATGGACAGGAA; SalT rev, AAGTGAGCG GACCAGGTGCT; Bowman-Birk fw, GGCGACACCATGA TCCGTCT; Bowman-Birk rev, CCCAGTAGACGTCCTCG CAGA; Actin1 fw, CGCAGTCCAAGAGGGGTATC; Actin 1 rev, TCCTGGTCATAGTCCAGGGC (for Actin1, Yamaguchi et al. 2002).

\section{ACKNOWLEDGMENTS}

We thank D. Brar, International Rice Research Institute (IRRI), Los Banos, Philippines, for supplying rice seeds. We also thank Bruker Daltronics, Bremen, for MS/MS analyses of protein spots 46, 102, 107, and 108, K. Niehaus, University Bielefeld, for MS analysis of protein 55 and K. Rischka, Fraunhofer Institut IFAM, Bremen, for permission of mass spectrometer use. We would also like to thank T. Hurek for critical reading of the article. This work was supported in part by grant RE756/6-1 from the Deutsche Forschungsgemeinschaft, and by grants from the BMBF (0311946 and GenoMik 031U213D) to B. Reinhold-Hurek.

\section{LITERATURE CITED}

Agrawal, G. K., Jwa, N. S., and Rakwal, R. 2000. A novel rice (Oryza sativa L.) acidic PR1 gene highly responsive to cut, phytohormones, and protein phosphatase inhibitors. Biochem. Biophys. Res. Comm. 274:157-165.

Bantignies, B., Seguin, J., Muzac, I., Dedaldechamp, F., Gulick, P., and Ibrahim, R. 2000. Direct evidence for ribonucleolytic activity of a PR10-like protein from white lupin roots. Plant Mol. Biol. 42:871-881.

Barraquio, W. L., Revilla, L., and Ladha, J. K. 1997. Isolation of endophytic diazotrophic bacteria from wetland rice. Plant Soil 194:15-24.

Berger, S. 2002. Jasmonate-related mutants of Arabidopsis as tools for studying stress signaling. Planta 214:497-504.

Claes, B., Dekeyser, R., Villarroel, R., Van den Bulcke, M., Bauw, G., Van Montagu, M., and Caplan, A. 1990. Characterization of a rice gene showing organ-specific expression in response to salt stress and drought. Plant Cell 2:19-27.

Czernic, P., Visser, B., Sun, W., Savoure, A., Deslandes, L., Marco, Y., Van Montagu, M., and Verbruggen, N. 1999. Characterization of an Arabidopsis thaliana receptor-like protein kinase gene activated by oxidative stress and pathogen attack. Plant J. 18:321-327.

de Souza Filho, G. A., Ferreira, B. S., Dias, J. M., Queiroz, K. S., Branco, A. T., Bressan-Smith, R. E., Oliveira, J. G., and Garcia, A. B. 2003. Accumulation of SALT protein in rice plants as a response to environmental stresses. Plant Sci. 164:623-628.

Egener, T., Hurek, T., and Reinhold-Hurek, B. 1999. Endophytic expression of nif genes of Azoarcus sp. strain $\mathrm{BH} 72$ in rice roots. Mol. PlantMicrobe Interact. 12:813-819.

Glazebrook, J. 1999. Genes controlling expression of defense responses in Arabidopsis. Curr. Opin. Plant Biol. 2:280-286.

Goff, S. A., Ricke, D., Lan, T. H., Presting, G., Wang, R., Dunn, M., Glazebrook, J., Sessions, A., Oeller, P., Varma, H., Hadley, D., Hutchison, D., Martin, C., Katagiri, F., Lange, B. M., Moughamer, T., Xia, Y., Budworth, P., Zhong, J., Miguel, T., Paszkowski, U., Zhang, S., Colbert, M., Sun, W. L., Chen, L., Cooper, B., Park, S., Wood, T. C., Mao, L., Quail, P., Wing, R., Dean, R., Yu, Y., Zharkikh, A., Shen, R., Sahasrabudhe, S., Thomas, A., Cannings, R., Gutin, A., Pruss, D., Reid, J., Tavtigian, S., Mitchell, J., Eldredge, G., Scholl, T., Miller, R. M., Bhatnagar, S., Adey, N., Rubano, T., Tusneem, N., Robinson, R., Feldhaus, J., Macalma, T., Oliphant, A., and Briggs, S. 2002. A draft sequence of the rice genome (Oryza sativa L. ssp. japonica). Science 296:92-100.

Hashimoto, M., Kisseleva, L., Sawa, S., Furukawa, T., Komatsu, S., and Koshiba, T. 2004. A novel rice PR10 protein, RSOsPR10, specifically induced in roots by biotic and abiotic stresses, possibly via the jasmonic acid signaling pathway. Plant Cell Physiol. 45:550-559.

Hause, B., Maier, W., Miersch, O., Kramell, R., and Strack, D. 2002. Induction of jasmonate biosynthesis in arbuscular mycorrhizal barley roots. Plant Physiol. 130:1213-1220.

Hurek, T., and Reinhold-Hurek, B. 2003. Azoarcus sp. strain BH72 as a model for nitrogen-fixing grass endophytes. J. Biotechnol. 106:169178.

Hurek, T., Reinhold-Hurek, B., Van Montagu, M., and Kellenberger, E. 1994. Root colonization and systemic spreading of Azoarcus sp. strain BH72 in grasses. J. Bacteriol. 176:1913-1923.

Hurek, T., Handley, L. L., Reinhold-Hurek , B., and Piché, Y. 2002. Azoarcus grass endophytes contribute fixed nitrogen to the plant in an unculturable state. Mol. Plant-Microbe Interact. 15:233-242.

Iniguez, A. L., Dong, Y., and Triplett, E. W. 2004. Nitrogen fixation in wheat provided by Klebsiella pneumoniae 342. Mol. Plant-Microbe Interact. 17:1078-1085.

Iniguez, A. L., Dong, Y., Carter, H. D., Ahmer. B. M. M., Stone, J. M., and Triplett, E. W. 2005. Regulation of enteric endophytic bacterial colonization by plant defense. Mol. Plant-Microbe Interact. 18:169-178.

James, E. K., and Olivares, F. L. 1998. Infection and colonization of sugar cane and other graminaceous plants by endophytic diazotrophs. Crit. Rev. Plant Sci. 17:77-119. 
James, E. K., Reis, V. M., Olivares, F. L., Baldandi, J. I., and Döbereiner, J. 1994. Infection of sugar cane by the nitrogen-fixing bacterium Acetobacter diazotrophicus. J. Exp. Bot. 45:757-766.

James, E. K., Olivares, F. L., Baldani, J. I., and Döbereiner, J. 1997. Herbaspirillum, an endophytic diazotroph colonizing vascular tissue in leaves of Sorghum bicolor L. Moench. J. Exp. Bot. 48:785-797.

Kim, S. T., Cho, K. S., Yu, S., Kim, S. G., Hong, J. C., Han, C. D., Bae, D. W., Nam, M. H., and Kang, K. Y. 2003. Proteomic analysis of differentially expressed proteins induced by rice blast fungus and elicitor in suspension-cultured rice cells. Proteomics 3:2368-2378.

Konishi, H., Kitano, H., and Komatsu, S. 2005. Identification of rice root proteins regulated by gibberellin using proteome analysis. Plant Cell Environ. 28:328-339.

Kunkel, B. N., and Brooks, D. M. 2002. Cross talk between signaling pathways in pathogen defense. Curr. Opin. Plant Biol. 5:325-331.

Lane, B. G. 2002. Oxalate, germins, and higher-plant pathogens. IUBMB Life 53:67-75.

Lange, J., Xie, Y.-P., Broughton, W. J., Vögeli-Lange, R., and Boller, T. 1999. A gene encoding a receptor-like protein kinase in the roots of common bean is differentially regulated in response to pathogens, symbionts and nodulation factors. Plant Sci. 142:133-145.

Liu, J., Blaylock, L. A., Endre, G., Cho, J., Town, C. D., VandenBosch, K. A., and Harrison, M. J. 2003. Transcript profiling coupled with spatial expression analyses reveals genes involved in distinct developmental stages of an arbuscular mycorrhizal symbiosis. Plant Cell 15:21062123

Majoul, T., Chahed, K., Zamiti, E., Ouelhazi, L., and Ghrir, R. 2000 Analysis by two-dimensional electrophoresis of the effect of salt stress on the polypeptide patterns in roots of a salt-tolerant and a salt-sensitive cultivar of wheat. Electrophoresis 21:2562-2565.

McGee, J. D., Hamer, J. E., and Hodges, T. K. 2001. Characterization of a $P R-10$ pathogenesis-related gene family induced in rice during infection with Magnaporthe grisea. Mol. Plant-Microbe Interact. 14:877-886.

Montesano, M., Koiv, V., Mae, A., and Palva, E. T. 2001. Novel receptorlike protein kinases induced by Erwinia carotovora and short oligogalacturonides in potato. Mol. Plant Pathol. 2:339-346.

Moons, A., Prinsen, E., Bauw, G., and Van Montagu, M. 1997. Antagonistic effects of abscisic acid and jasmonates on salt stress-inducible transcripts in rice roots. Plant Cell 9:2243-2259.

Passardi, F., Penel, C., and Dunand, C. 2004. Performing the paradoxical: How plant peroxidases modify the cell wall. Trends Plant Sci. 9:534540.

Qu, L. J., Chen, J., Liu, M., Pan, N., Okamoto, H., Lin, Z., Li, C., Li, D. Wang, J., Zhu, G., Zhao, X., Chen, X., Gu, H., and Chen, Z. 2003. Molecular cloning and functional analysis of a novel type of Bowman-Birk inhibitor gene family in rice. Plant Physiol. 133:560-570.

Rakwal, R., and Komatsu, S. 2000. Role of jasmonate in the rice (Oryza sativa L.) self-defense mechanism using proteome analysis. Electrophoresis 21:2492-2500.

Rakwal, R., Agrawal, G. K., and Yonekura, M. 1999. Separation of proteins from stressed rice (Oryza sativa L.) leaf tissues by two-dimensional polyacrylamide gel electrophoresis: Induction of pathogenesisrelated and cellular protectant proteins by jasmonic acid, UV irradiation and copper chloride. Electrophoresis 20:3472-3478.

Rakwal, R., Agrawal, G. K., and Jwa, N. S. 2001. Characterization of a rice (Oryza sativa L.) Bowman-Birk proteinase inhibitor: Tightly light regulated induction in response to cut, jasmonic acid, ethylene and protein phosphatase 2A inhibitors. Gene 263:189-198.

Reinhold, B., Hurek, T., Niemann, E.-G., and Fendrik, I. 1986. Close association of Azospirillum and diazotrophic rods with different root zones of Kallar grass. Appl. Environ. Microbiol. 52:520-526.

Reinhold-Hurek, B., and Hurek, T. 1998a. Interactions of gramineous plants with Azoarcus spp. and other diazotrophs: Identification, localization and perspectives to study their function. Crit. Rev. Plant Sci. 17:29-54.

Reinhold-Hurek, B., and Hurek, T. 1998b. Life in grasses: Diazotrophic endophytes. Trends Microbiol. 6:139-144.

Reinhold-Hurek, B., Hurek, T., Claeyssens, M., and Van Montagu, M. 1993. Cloning, expression in Escherichia coli, and characterization of cellulolytic enzymes of Azoarcus sp., a root-invading diazotroph. J. Bacteriol. 175:7056-7065.

Salekdeh, G. H., Siopongco, J., Wade, L. J., Ghareyazie, B., and Bennett, J. 2002. A proteomic approach to analyzing drought- and salt-responsiveness in rice. Field Crops Res. 76:199-219.

Sevilla, M., Burris, R. H., Gunapala, N., and Kennedy, C. 2001. Comparison of benefit to sugarcane plant growth and ${ }^{15} \mathrm{~N}_{2}$ incorporation following inoculation of sterile plants with Acetobacter diazotrophicus wildtype and nif $^{-}$mutant strains. Mol. Plant-Microbe Interact. 14:358-366.

Shen, S., Jing, Y., and Kuang, T. 2003. Proteomics approach to identify wound-response related proteins from rice leaf sheath. Proteomics 3:527-535.

Shevchenko, A., Wilm, M., Vorm, O., and Mann, M. 1996. Mass spectrometric sequencing of proteins from silver-stained polyacrylamide gels Anal. Chem. 68:850-858.

Silverman, P., Seskar, M., Kanter, D., Schweizer, P., Metraux, J. P., and Raskin, I. 1995. Salicylic acid in rice biosynthesis, conjugation, and possible role). Plant Physiol. 108:633-639.

Turner, J. G., Ellis, C., and Devoto, A. 2002. The jasmonate signal pathway. Plant Cell 14:S153-S164.

Van Damme, E. J., Zhang, W., and Peumans, W. J. 2004. Induction of cytoplasmic mannose-binding jacalin-related lectins is a common phenomenon in cereals treated with jasmonate methyl ester. Comm. Appl. Biol. Sci. 69:23-31.

van Loon, L. C., and van Strien, E. A. 1999. The families of pathogenesisrelated proteins, their activities, and comparative analysis of PR-1 type proteins. Physiol. Mol Plant Pathol. 55:85-97.

van Loon, L. C., Bakker, P. A., and Pieterse, C. M. 1998. Systemic resistance induced by rhizosphere bacteria. Annu. Rev. Phytopathol. 36:453483.

Vernoud, V., Horton, A. C., Yang, Z., and Nielsen, E. 2003. Analysis of the small GTPase gene superfamily of Arabidopsis. Plant Physiol. 131:1191-1208

Wang, K. L., Li, H., and Ecker, J. R. 2002. Ethylene biosynthesis and signaling networks. Plant Cell 14 Suppl:S131-151.

Wang, Y., Ohara, Y., Nakayashiki, H., Tosa, Y., and Mayama, S. 2005. Microarray analysis of the gene expression profile induced by the endophytic plant growth-promoting rhizobacteria, Pseudomonas fluorescens FTP9601-T5 in Arabidopsis. Mol. Plant-Microbe Interact. 18:385-396.

Yamaguchi, T., Nakayama, K., Hayashi, T., Tanaka, Y., and Koike, S. 2002. Molecular cloning and characterization of a novel beta-1,3-glucanase gene from rice. Biosci. Biotech. Biochem. 66:1403-1406.

Yanni, Y. G., Rizk, R. Y., Corich, V., Squartini, A., Ninke, K., PhilipHollingsworth, S., Orgambide, G., De Bruijn, F., Stoltzfus, J., Buckley, D., Schmidt, T. M., Mateos, P. F., Ladha, J. K., and Dazzo, F. B. 1997. Natural endophytic association between Rhizobium leguminosarum bv. trifolii and rice roots and assessment of its potential to promote rice growth. Plant Soil 194:99-114.

Yu, J., Hu, S., Wang, J., Wong, G. K., Li, S., Liu, B., Deng, Y., Dai, L., Zhou Y., Zhang, X., Cao, M., Liu, J., Sun, J., Tang, J., Chen, Y., Huang, X., Lin, W., Ye, C., Tong, W., Cong, L., Geng, J., Han, Y., Li, L., Li, W., Hu, G., Li, J., Liu, Z., Qi, Q., Li, T., Wang, X., Lu, H., Wu, T., Zhu, M., Ni, P., Han, H., Dong, W., Ren, X., Feng, X., Cui, P., Li, X., Wang, H., Xu, X., Zhai, W., Xu, Z., Zhang, J., He, S., Xu, J., Zhang, K., Zheng, X., Dong, J., Zeng, W., Tao, L., Ye, J., Tan, J., Chen, X., He, J., Liu, D., Tian, W., Tian, C., Xia, H., Bao, Q., Li, G., Gao, H., Cao, T., Zhao, W., Li, P., Chen, W., Zhang, Y., Hu, J., Liu, S., Yang, J., Zhang, G., Xiong, Y., Li, Z., Mao, L., Zhou, C., Zhu, Z., Chen, R., Hao, B., Zheng, W., Chen, S., Guo, W., Tao, M., Zhu, L., Yuan, L., and Yang, H. 2002. A draft sequence of the rice genome (Oryza sativa L. ssp. indica). Science 296:79-92.

\section{AUTHOR-RECOMMENDED INTERNET RESOURCES}

Technical University of Denmark, Center for Biological Sequence Analysis, NetPhos 2_0: www.cbs.dtu.dk/services/NetPhos

ProteoMetrics ProFound Advanced software: 65.219.84.5/service/prowl/profound/profound_E_adv.html Matrix Science website: www.matrixscience.com 